\title{
ANALISIS VOLATILITAS NILAI TUKAR MATA UANG RUPIAH TERHADAP DOLAR
}

\author{
Imam Mukhlis \\ Fakultas Ekonomi Universitas Negeri Malang
}

\begin{abstract}
This research aims to analyze the volatility of exchange rate (Rp/US\$) on the Indonesian economy. The Method of analyze uses Autoregressive Conditional Heteroscedasticiy (ARCH)/Generalized Autoregressive Conditional Heteroscedasticiy (GARCH) that was developed by Arize, (1995) and Zainal (2004). The result show that volatility of exchange rate (Rp/US\$) has extreme point at 1997/1998. At that time, economic crisis was happen on the Indonesian economy, where the value of exchange rate volatility Rp/US\$ have reached at point 0,250.
\end{abstract}

Keywords : volatility, exchange rate, ARCH,GARCH

\section{A. LATAR BELAKANG}

Liberalisasi dan globalisasi yang melanda dunia dewasa ini telah merubah perekonomian di berbagai negara menjadi semakin terbuka. Arus keluar masuk barang, jasa dan modal menjadi semakin mudah menembus batas-batas teritorial suatu negara. Konsep borderless menjadi menguat dalam konteks perekonomian dunia seiring dengan keterbukaan perekonomian domestik terhadap penetrasi dari luar negeri. Dalam konteks ini, integrasi perekonomian suatu negara ke dalam perekonomian global menjadi bukan menjadi pilihan, dimana mau atau tidak mau suatu negara memiliki keharusan untuk masuk dalam pasar bebas. Sebagai konsekuensinya, setiap negara akan memiliki ketergantungan satu dengan yang lainnya baik menyangkut aspek perdagangan barang dan jasa secara internasional dan integrasi pasar keuangan di berbagai negara (Abel and Bernanke,2004:468).

Dalam perkembangannya, arus liberalisasi dan globalisasi dunia dewasa ini telah menyebabkan kekawatiran tersendiri bagi setiap negara. Untuk mensikapi dinamika yang terjadi, setiap negara merumuskan suatu kerangka kerjasama multisektor. Salah satu dampak dari adanya liberalisasi dan globalisasi tersebut adalah semakin transparannya perekonomian setiap negara. Melalui interaksi ekonomi yang ada, setiap negara mampu melaksanakan kegiatan ekonominya sesuai dengan endowment factor yang dimilikinya. Kemampuan suatu negara dalam memberdayakan endowment factor tersebut akan berdampak pada kemampuannya dalam meningkatkan kapasitas perekonomiannya. 
Pada sisi lain juga dapat dijelaskan bahwa liberalisasi dan globalisasi yang ada membawa konsekuensi pada fundamental perekonomian masing-masing negara. Ketidakmampuan negara dalam menjaga fundamental perekonomian ini dapat berdampak pada kestabilan ekonomi makro. Salah satu indikator ekonomi makro yang sensitif terhadap gejolak perekonomian eksternal adalah nilai tukar mata uang (kurs mata uang). Dalam hal ini nilai tukar mata uang mencerminkan kekuatan perekonomian sebagai akibat dari penetrasi dan efek dari perekonomian global. Semakin stabil nilai tukar mata uang suatu negara terhadap mata uang negara lain, semakin menunjukkan kekuatan fundamental perekonomian negara tersebut. Dengan kata lain, pemerintah (otoritas moneter) mampu melakukan kebijakan moneter dan dari nilai tukar mata uang yang dapat mendorong peningkatan daya saing perekonomian suatu negara.

Naik turunnya nilai tukar mata uang di pasar uang (apresiasi dan depresiasi) menunjukkan besarnya volatilitas yang terjadi pada mata uang suatu negara dengan mata uang negara lain (Chou, 2000). Volatilitas yang semakin besar menunjukkan pergerakan kurs yang semakin besar (apresiasi/depresiasi mata uang). Hal ini memberikan gambaran terjadinya overvalued dan undervalued nilai tukar mata uang terhadap mata uang negara lainnya. Manakala nila tukar mata uang mengalami volatilitas yang ekstrim, maka perekonomian akan mengalami ketidakstabilan baik dari sisi makro dan mikro.

Berbagai penelitian mencoba menganalisis aspek volatilitas nilai tukar mata uang. Hal ini didasari oleh sebuah fakta bahwa pergerakan nilai tukar mata uang akan berpengaruh pada kegiatan perdagangan internasional, neraca pembayaran (balance payment) dan stabilitas perekonomian secara makro. Hasil penelitian yang dilakukan oleh Asseery dan Peel (1991); Bailey et al. (1992) memberikan hasil bahwa pengaruh volatilitas nilai tukar mata uang terhadap aliran perdagangan internasional masih bersifat lack of conclusive and ambiguous.

Sedangkan penelitian oleh Agolli (2007) memberikan kesimpulan bahwa volatilitas nilai tukar mata uang berpengaruh positif signifikan terhadap permintaan impor di negara-negara Eropa (Jerman, Italia dan dan Yunani) selama tahun 1993-2003. Pada hasil penelitian oleh Suselo, dkk (2008) memberikan kesimpulan bahwa volatilitas nilai tukar mata uang memiliki pengaruh negatif terhadap permintaan impor Indonesia dari dunia selama tahun 1990-2005.

Berdasarkan Baldwin and Krugman hysteresis dinyatakan bahwa pergerakan dalam nilai tukar mata uang memiliki dampak yang berbeda-beda terhadap sektor kegiatan ekonomi, tergantung dari karakteristik khusus dari setiap industri. Karakteristik ini seperti tingkat investasi awal, tingkat substitusi barang dan ketahanan produk (durable good/nondurable good). Dalam hal ini sektor kegiatan ekonomi dengan kebutuhan investasi awal yang sedikit akan cenderung untuk lebih sensitif terhadap volatilitas nilai tukar matang uang. Sedangkan sektor ekonomi dengan tingkat kebutuhan investasi awal yang cukup besar tidak sensitif terhadap volatilitas nilai tukar mata uang (Larson, dkk,2005:10).

Perekonomian Indonesia hingga kini masih sangat rentan terhadap gejolak perekonomian dari luar negeri. Keterbukaan perekonomian yag tercermin dalam strategi pengembangan industri nasional yang berorientasi ke luar (outward looking strategy) berdampak pada pergerakan nilai tukar mata uang (khususnya Rp/US\$) yang semakin bebas. Sebagai gambaran dari perkembangan nilai tukar mata uang Rp/US seperti gambar 1 . 


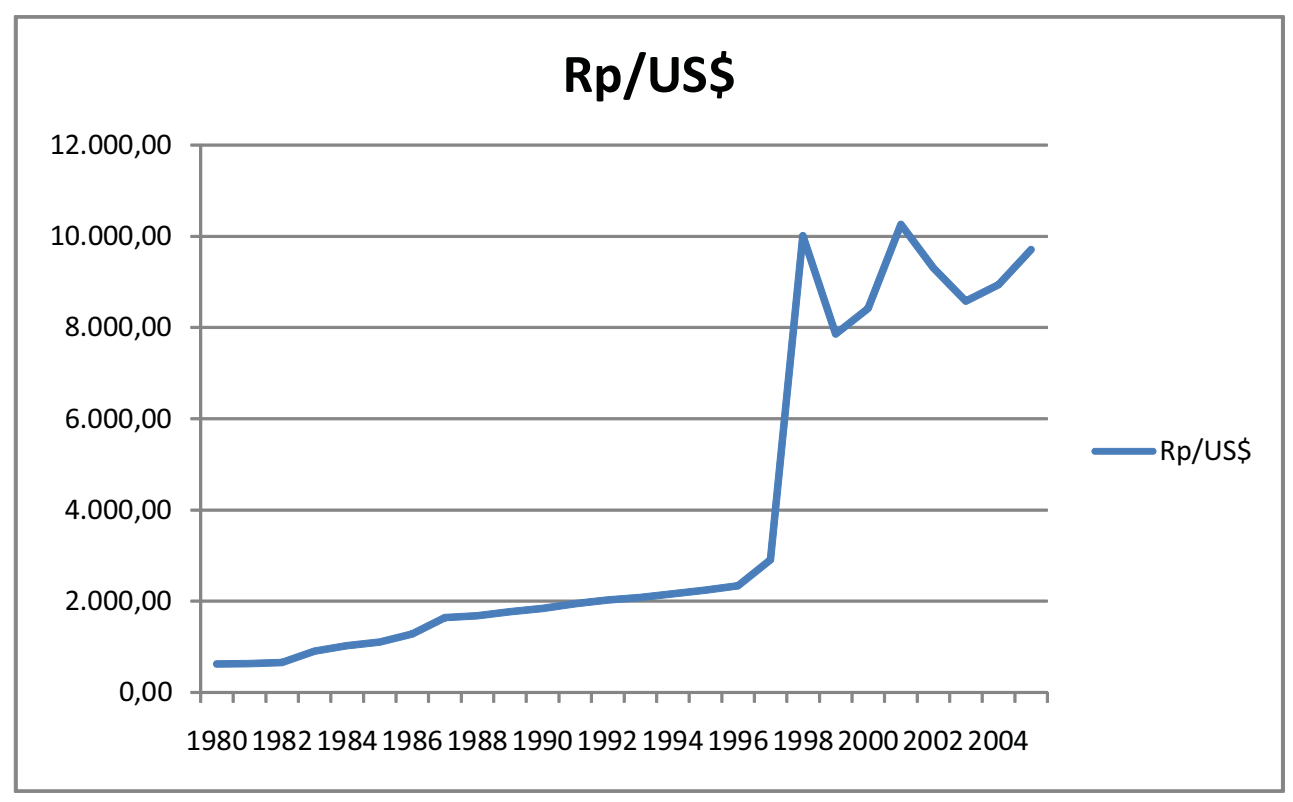

Gambar 1. Perkembangan Nilai Kurs Rp/US\$ Sumber: International Financial Statistics dari IMF, 2010

Berdasarkan pada gambar di atas dapat dijelaskan bahwa periode sebelum krisis 1997/ 1998 nilai tukar mata uang relatif stabil pada kisaran Rp.2.000/US\$-Rp.3.000/US\$. Kestabilan nilai tukar ini salah satunya diakibatkan oleh sistem nilia tukar yang dianut yakni sistem Managed floating dengan crawling band system yang diterapkan sejak 1992-1997. Namun setelah periode krisis ekonomi tersebut sistem nilai tukar menganut sistem mengambang bebas (free floating exchange rate system). Dampak dari naik turunnya nila tukar tersebut dapat menyebabkan perekonomian mengalami fluktuasi output yang dihasilkannya. Selain itu pula fluktuasi yang terjadi tersebut mengharuskan otoritas moneter untuk melakukan intervensi pasar yang ditujukan untuk menjaga nilai tukar mata uang Rp/US\$ agar tidak keluar dari interval kurs yang telah ditetapkannya. Berdasarkan pada uraian di atas, maka penelitian ini bertujuan untuk menganalisis volatilitas nilai tukar mata uang Rp/US\$ selama periode 1980-2005.

\section{B. KAJIAN TEORITIS}

Pergerakan nilai tukar mata uang mencerminkan harga relatif suatu mata uang terhadap mata uang lain. Fluktuasi dalam perkembangan nilai tukar mata uang akan mengakibatkan perubahan perilaku economic agent dalam keputusan bisnisnya. Pergerakan nilai tukar yang overvalued, akan berimplikasi pada semakin mahalnya harga barang impor dalam persepsi mata uang domestik. Hal ini akan berdampak pada semakin berkurangnya daya beli importir dalam pemenuhan kebutuhan produknya. Sebaliknya manaka terjadi undervalued, maka bagi eksportir hal tersebut akan dapat mengurangi margin profit yang diterimanya dari produk yang laku di pasar internasional. 
Dampak pergerakan nilai tukar mata uang terhadap perilaku economic agent (eksportir dan impor) dapat dijelaskan melalui besarnya biaya dan harga yang muncul dari volatilitas nilai tukar. Dalam hal ini menurut Baldwin dan Meir (1989), biaya yang dibutuhkan oleh economic agent untuk masuk ke pasar tersebut merupakan sunk cost. Adanya volatilitas nilai tukar, tidak serta merta menyebabkan economic agent langsung ke luar dari pasar. Economic agent akan menunggu saat yang tepat dimana marjin keuntungan yang diperolehnya belum pada kondisi negatif (rugi). Selanjutnya menurut Baldwin dan Krugman tersebut pada kondisi terjadinya volatilitas tersebut, terdapat hubungan asimetris antara nilai tukar yang trigger entry and exit into the export market.

Pergerakan nilai tukar yang berfluktuasi di pasar uang tersebut akan sangat ditentukan oleh sistem nilai tukar yang dianut oleh masing-masing negara. Sistem nilai tukar mata uang yang bersifat fixed exchange rate, cenderung akan mengakibatkan stabilitas nilai tukar mata uang karena adanya supporting dari otoritas moneter dalam bentuk intervensi di pasar uang. Sedangkan sisten nilai tukar mata uang yang menganut floating exchange rate akan cenderung mengakibatkan pergerakan nilai tukar mata uang yang bersifat volatil. Pada jenis nilai tukar mata uang yang bersifat volatil ini, membawa konsekuensi pada kondisi ketidakpastian yang akan dihadapi oleh economic agent. Ketidakpastian tersebut merupakan teka-teki yang patut dicermati oleh semua fihak dalam menjaga stabiliatas makroekonomi. Dalam hal ini Krugman (dalam Adam, 1991:3) memberikan penjelasan yang menarik tentang adanya significant puzzle dalam perilaku nilai tukar mata uang dan harga suatu barang. Menurutnya volatilitas nilai tukar mata uang nominal yang sangat tinggi dapat mendorong adanya muted reaction terhadap harga barang riil dan hal ini dapat membawa konsekuensi pada kecilnya penyesuaian dalam volume barang yang diperdagangkan. Sehingga dengan demikian, pada dasarnya menurut pemikiran Krugman tersebut volatilitas nilai tukar mata uang tidak berpengaruh secara cepat terhadap harga.

Dalam pemikiran lain Krugman juga menjelaskan bahwa adanya sunk cost akan mendorong variabilitas pergerakan nilia tukar mata uang. Dalam modelnya yang dikenal dengan hysteresis model, dijelaskan bahwa sekali nilai tukar mata uang bergerak dengan sejumlah tertentu entry dan exit yang akan terjadi di pasar. Pandangan utama Krugman adalah marjin pada kejadian hyeteresis akan berbeda dengan sejumlah variabiltas nilai tukar yang terjadi. Nilai tukar mata uang yang terjadi sebelumnya akan digunakan untuk membentuk ekspektasi tentang perubahan nilai tukar. Semakin besar volatilitas nilai tukar sekarang akan berdampak pada semakin besarnya volatilitas di masa depan.

Pada sisi lain Baldwin (1988) juga menjelaskan bahwa berdasarkan bukti empiris yang diperolehnya menunjukkan adanya sebuah puzzle tentang import-price sluggishness dan hal tersebut mengakibatan terjadinya hysteresis dalam keputusan keluar masuk pasar. Dalam hal ini pada dasarnya Krugman tidak menjelaskan secara riil adanya price sluggshness. Nilai tukar mata uang yang berada pada posisi rendah (low level) pass through dari nilai tukar dari impor barang membutuhkan penjelasan. Dalam hal ini Baldwin mengajukan penggunaan idea of path dependence di perusahaan yang memiliki keputusan harga secara langsung. Selain itu pula dalam penjelasannya Baldwin juga menjelaskan adanya hubungan terbalik antara the size of the pass through dan volatilitas dari nilai tukar mata uang. Sedangkan pemikiran Krugman tidak fokus secara khusus pada pass-through elasticity. 
Dalam teori histeresis model Baldwin dan Krugman tersebut pada dasarnya dinyatakan bahwa ...unexpected bilateral exchange rate misalignment can cause a permanent change in market structure (Baldwin, 1988; Baldwin dan Krugman, 1989). Dalam hal ini model histeresis dan bukti empiris menunjukkan bahwa perubahan dalam nilai tukar membawa perbedaan dalam dampak terhadap berbagai sektor, tergantung karakteristik khusus dari setiap industri. Karakteristik tersebut seperti investasi awal (Baldwin, 1988), tingkat substitusi barang (Dornbusch, 1987) dan ada tidaknya produk yang durable (Foot dan Klemperer, 1989).

\section{METODE PENELITIAN DAN ANALISIS DATA}

\section{Jenis dan Sumber Data}

Data yang digunakan dalam penelitian ini adalah data sekunder runtun waktu (time series). Data ini dibutuhkan karena penelitian ini menganalisis fenomena ekonomi secara agregat, yakni fluktuasi nilai tukar mata uang Rp/US\$ selama periode waktu 1980-2005. Data yang digunakan dalam penelitian ini adalah nilai tukar mata uang Rp/US\$.Sedangkan sumber datanya adalah publikasi International Financial Statistics dari IMF (annual report).

\section{Pengukuran Volatilitas Nilai Tukar Mata Uang (Rp/US\$)}

Volatilitas nilai tukar mata uang menunjukkan fluktuasi nilai tukar mata sebagai dampak dari faktor-faktor yang mempengaruhinya. Pengukuran volatilitas mata uang ini secara kuantitatif dapat dilakukan dengan pendekatan Moving Average Standard Deviation (MASD) (Vergil, 2002 ; Scnabl, 2007) dan pendekatan Autoregressive Conditional Heteroscedasticiy (ARCH)/ Generalized Autoregressive Conditional Heteroscedasticiy (GARCH) (Arize, 1995 ; Zainal, 2004). Dalam penelitian ini pengukuran volatilitas menggunakan pendekatan ARCH/GARCH. Hal ini karena pendekatan ARCH/GARCH mampu mengukur ketidakpastian dalam pergerakan nilai tukar mata uang atas informasi yang tersedia pada periode sebelumnya (Pozo,1992).

Adapun model GARCH yang digunakan dalam mengukur volatilitas nilai tukar mata uang dalam penelitian ini dapat dirumuskan sebagai berikut ini :

$$
\begin{aligned}
& \operatorname{LER}_{t}=a+z^{2} \operatorname{LER}_{t-1}+e_{t} \\
& h_{t}=k+l^{2}{ }_{t-1}+m_{t-1} \ldots
\end{aligned}
$$

dimana :

LER merupakan log dari nilai tukar mata uang Rp/US\$

h merupakan variance dari error term $\mathrm{e}_{\mathrm{t}}$

a dan k merupakan konstanta

$\mathrm{z}, 1$, dan m merupakan koefisien dari masing-masing variabel

e merupakan error term 
Berdasarkan persamaan di atas, pendekatan dalam ARCH/GARCH terbagi dalam 2 persamaan, yakni persamaan mean variance (1) dan persamaan conditional variance (2). Persamaan mean variance digunakan untuk mendapatkan nilai error term dan persamaan conditional variance digunakan untuk mendapatkan nilai volatilitas nilai tukar mata uang $\mathrm{Rp} /$ US\$. Pada persamaan conditional variance tersebut dapat diketahui besarnya ARCH $\left(\mathrm{e}^{2}{ }_{\mathrm{t}-1}\right)$ dan besarnya GARCH $\left(h_{t-1}\right)$ untuk mendapatkan nilai $h_{t}$ sebagai pendekatan nilai volatilitas nilai tukar mata uang. Sehingga dengan demikian volatilitas nilai tukar mata uang dapat diukur dengan besaran nilai dari eror term variance $\left(\mathrm{h}_{\mathrm{t}}\right)$ pada persamaan (2).

Persamaan (2) tersebut merupakan prediksi pelaku ekonomi terhadap variasi (variance) nilai tukar mata uang periode sekarang. Variasi nilai tukar merupakan fungsi dari 3 faktor, yakni ; rata-rata variance, informasi tentang pergerakan nilai tukar mata uang (volatilitas) dari periode sebelumnya dan nilai prediksi error variance periode sebelumnya (Zainal, 2004:70).

Menurut Pozo (1992) alternatif penggunaan model ARCH/GARCH dalam pengukuran volatilitas tersebut karena kemampuannya dalam menjelaskan perilaku nilai tukar mata uang yang tidak pasti. Spesifikasi model ARCH/GARCH tersebut dapat digunakan untuk mengestimasi variance perubahan nilai tukar mata uang sebagai time dependent. Spesifikasi time dependent tersebut dapat digunakan untuk menjelaskan pattern and persistence dalam perilaku volatilitas nilai tukar mata uang (Zainal, 2004:33).

\section{HASIL DAN PEMBAHASAN}

Hasil perhitungan nilai volatilitas dalam penelitian ini menggunakan data kurs riil nilai tukar Rp/US\$ bulanan selama tahun 1980-2005 dengan menggunakan harga konstan tahun 2000. Berdasarkan data kurs Rp/US\$ tersebut kemudian dilakukan perhitungan untuk mendapatkan hasil estimasi seperti pada persamaan (1) dan persamaan (2). Hasil estimasi persamaan tersebut adalah:

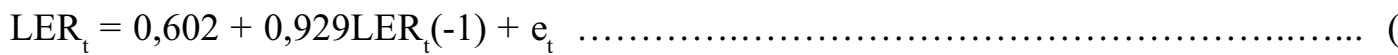

$$
\begin{aligned}
& (19,26) \quad(250,9) \\
& \mathrm{h}_{\mathrm{t}}=0,00003+2,319 \mathrm{e}_{\mathrm{t}-1}^{2}+0,188 \mathrm{~h}_{\mathrm{t}-1}+\mathrm{e}_{\mathrm{t}}
\end{aligned}
$$

Nilai volatilitas bulanan nilai tukar mata uang Rp/US\$ dapat diperoleh dari persamaan (2) yakni dengan memasukkan nilai error term/residual persamaan (1) dan nilai error term variance periode sebelumnya. Sedangkan data nilai tahunan volatilitas diperoleh dengan cara menghitung rata-rata tiap bulannya setiap tahun. Secara lebih lengkap nilai volatilitas nilai tukar mata uang Rp/US\$ dapat dilihat pada gambar 2 . 


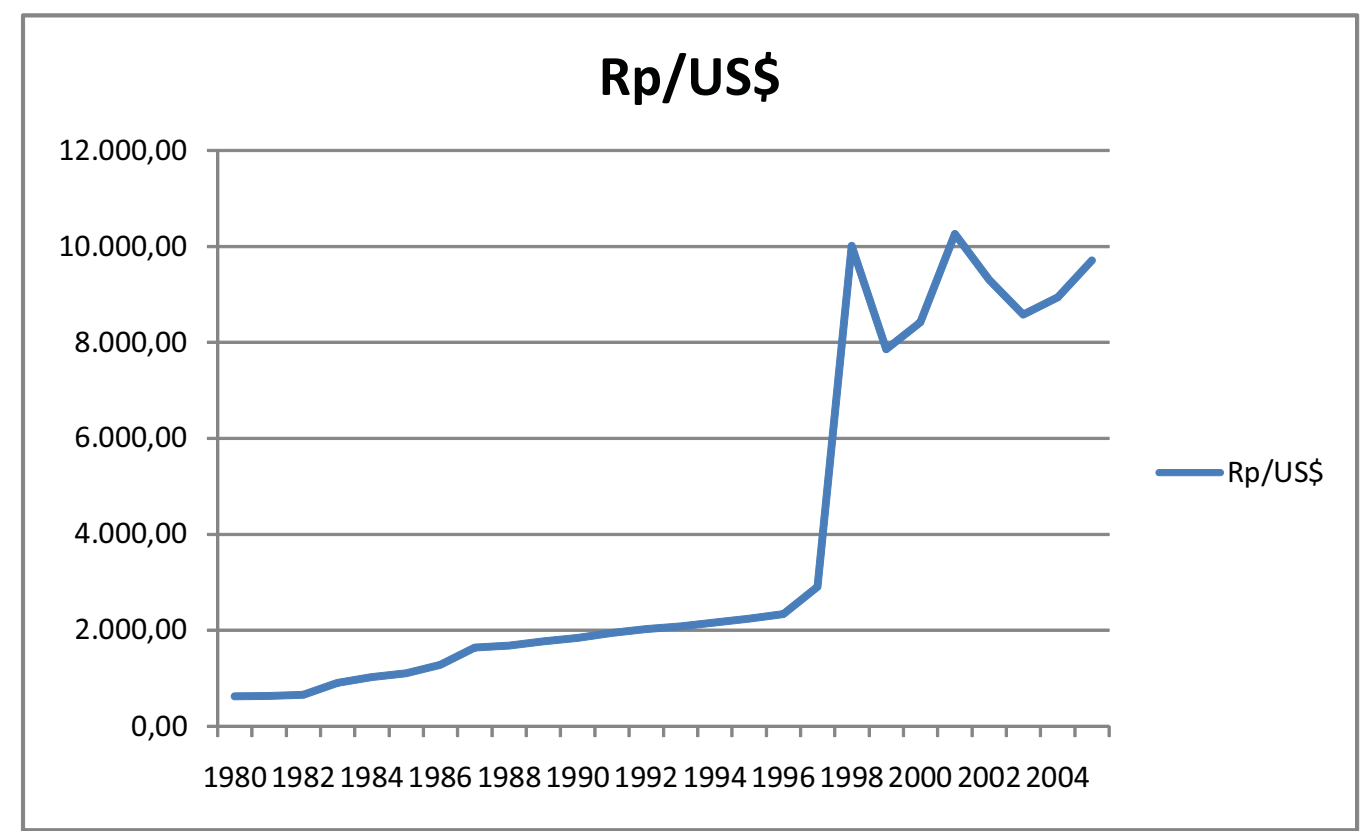

Gambar 2. Perkembangan Volatilitas Nilai Tukar Mata Uang Rp/Us\$ Sumber: Data diolah, tidak dilampirkan

Perkembangan volatilitas nilai tukar mata uang Rp/US\$ selama tahun 1980-2005 menunjukkan nilai yang berfluktuatif. Periode tahun 1980-1987 nilai volatilitas menunjukkan fluktuasi yang relatif rendah. Nilai tertinggi volatilitas nilai tukar rupiah yaitu pada tahun 1998 dengan nilai Volatilitas sebesar 0.248375 . Kenaikan secara drastis nilai volatiltias ini disebabkan adanya krisis ekonomi yang terjadi pada tahun 1997-1998. Krisis ekonomi yang terjadi menyebabkan nilai tukar Rp/US\$ mengalami depresiasi yang sangat tajam, sehingga menyebabkan fluktuasi nilai tukar mata uang Rp/US\$ menjadi tidak stabil. Kemudian pasca krisi ekonomi terjadi, serangkaian kebijaksanaan moneter yang dilakukan oleh pemerintah (Bank Indonesia) pada akhirnya dapat meredam fluktuasi nilai tukar mata uang hingga terjadi kestabilan dalam volatilitasnya pada periode tahun 2000-2005.

Volatilitas nilai tukar mata uang menurut Rudiger Dornbusch tahan 1976 dalam papernya yang berjudul Expectations and Exchange Rate Dynamics dinyatakan bahwa "....stickiness of goods prices forced exchange rates to carry all the shortrun adjustment of the economy in response to unanticipated monetary shocks...". Berdasarkan pada pemahaman tersebut dapat dijelaskan lagi bahwa ketidakpastian yang terjadi pada sektor moneter dapat berdampak pada pergerakan nilai tukar mata uang. Dalam konteks perekonomian Indonesia, gejolak perekonomian eksternal yang terjadi selama ini memberikan peringatan (early warning system) bagi otoritas moneter dalam negeri untuk segera merespon dengan kebijaksanaan moneter yang sesuai dengan kondisi pasar. Manakala peringatan yang ada tidak mendapatkan respon positif dari otoritas moneter, maka hal tersebut dapat berdampak pada kegiatan perekonomian 
domestik. Krisis ekonomi yang terjadi pada periode 1997/1998 memberikan gambaran nyata akan gejolak eksternal yang terjadi dapat dengan cepat mempengaruhi fundamental perekonomian melalui jalur nilai tukar mata uang, tingkat bunga dan inflasi.

Sebagaimana diketahui bahwa pergerakan nilai tukar mata uang terjadi karena beberapa faktor eksternal yang ada seperti tingkat inflasi, tingkat suku bunga, harga saham, ekspektasi masyarakat dan perilaku spekulan di pasar uang. Secara teoretis pergerakan nilai tukar mata uang tersebut dapat mempengaruhi perilaku pelaku ekonomi dalam melakukan kegiatan perdagangan internasionalnya. Dalam hal ini apabila terjadi apresiasi nilai tukar mata uang Rp/US\$ akan berimplikasi pada semakin meningkatnya daya beli atas barang impor. Sebaliknya apabila terjadi depresiasi nilai tukar mata uang Rp/US\$ akan berimplikasi pada semakin menurunnya daya beli atas barang impor. Dalam konteks inilah maka volatilitas nilai tukar mata uang Rp/US\$ memiliki peran penting dalam perkembangan perdagangan suatu negara. Semakin tinggi volatilitas nilai tukar Rp mencerminkan semakin tingginya kesenjangan antara tingginya permintaan dan makin terbatasnya ketesediaan mata uang US\$ di pasar uang. Ketidakseimbangan ini dapat berakibat pada semakin besarnya biaya yang dikeluarkan importer dalam kegiatan impornya. Oleh karena itu guna menjamin stabilitas nilai tukar mata ini, bank sentral memiliki peran penting dalam melakukan pengawasan terhadap pergerakan nilai tukar mata uang.

Perkembangan sistem nilai tukar mata uang Rp/US\$ mengalami pasang surutnya. Secara garis besar periode sebelum tahun 1997 sistem nilai tukar mata uang Indonesia adalah sistem nilai tukar mengambang terkendali (Managed Floating Exchange Rate system) dan periode setelah krisis ekonomi tahun 1997 sistem nilai tukar mata uangnya lebih moderat, yakni sistem nilai tukar bebas (Free Exchange Rate system) (Zainal,2004:71). Secara lebih rinci perkembangan sistem nilai tukar mata uang Indonesia sebagai berikut ini:

Tabel 1. Perkembangan Sistem Nilai Tukar di Indonesia

\begin{tabular}{ll}
\hline \multicolumn{1}{c}{ Periode } & \multicolumn{1}{c}{ Sistem Nilai Tukar } \\
\hline 1960 an & Multiple exchange rate \\
Agustus 1971-November 1978 & Nilai tukar tetap \\
November 1978-September 1992 & Mengambang terkendali \\
September 1992-Agustus 1997 & Managed floating dengan crawling band system \\
Agustus 1997-sekarang & Sistem mengambang bebas \\
\hline Sumber : Sarwono dan Warjiyo, 1998 &
\end{tabular}

Berdasarkan pada tabel tersebut dapat dijelaskan bahwa kebijakan sistem nilai tukar di Indonesia menunjukkan perubahan dari waktu ke waktu seiring dengan perubahan yang terjadi dalam lingkungan ekonomi Indonesia. Secara garis besar perubahan sistem nilai tukar tersebut dari sistem nilai tukar tetap (fixed exchage rate) ke sistem nilai tukar mengambang bebas (free floating exchange rate). Perubahan dalam sistem nilai tukar ini terjadi karena Otoritas moneter Inodonesia menganggap bahwa dinamika perkembangan eksternal berjalan sedemikian cepat seiring dengan keterbukaan perekonomian nasional terhadap penetrasi pasar asing, sehingga pergerakan nilai tukar mata uang Rp/US\$ menjadi sulit untuk dikendalikan secara permanen. Dalam sistem nilai tukar mengambang tersebut pergerakan nilai tukar mata uang Rp/US\$ akan 
bergerak sesuai dengan mekanisme kekuatan permintaan/penawaran mata uang di pasar uang. Perubahan sistem nilai tukar ini pada akhirnya akan berpengaruh pada volatilitas nilai tukar mata uang Rupiah khususnya terhadap mata uang US\$.

Berdasarkan sistem nilai tukar mata uang yang dianut oleh Indonesia, periode waktu sebelum krisis ekonomi memberikan gambaran akan relatif stabilnya pergerakan nilai tukar mata uang $\mathrm{Rp} / \mathrm{US} \$$. Hal ini juga dapat dijelaskan dengan relatif rendahnya nilai volatilitas mata uang Rp/ US\$. Volatiltias nilai tukar mata uang Rp/US\$ mangalami puncaknya manakala terjadi krisis ekonomi pada tahun 1997. Ketidakstabilan perekonomian domestik sebagai akibat dari goncangan (shock) eksternal yang tejadi hampir di berbagai negara menyebabkan nilai tukar Rp/US\$ mengalami overestimate. Akibatnya nilai tukar mata uang Rp/US\$ mengalami depresiasi yang cukup tajam, sehingga hal tersebut mempengaruhi performance fundamental perekonomian domestik yang lainnya.

Pada tinjauan APBN dampak dari depresiasi mata uang Rp/US\$ tersebut khususnya akan semakin meningkatkan beban pengeluaran negara untuk pembayaran hutang luar negeri. Pergerakan nilai tukar mata uang tersebut pada sisi lain juga dapat meningkatkan penerimaan negara, manakala daya saing ekspor sangat tinggi sehingga hasil devisa ekspor yang diperoleh juga sangat besar. Namun dalam kondisi perekonomian dunia yang tidak stabil tentunya sangat sulit untuk meningkatkan kinerja ekspornya. Hal ini karena daya beli masyarakat luar negeri akan terganggu sebagai dampak dari terganggunya kegiatan ekonomi di masing-masing negara.

Bagi importir dalam negeri depresiasi mata uang Rp/US\$ tersebut juga berdampak pada kenaikan biaya produksi, manakala komponen produksi utamanya harus diimpor dari luar negeri. Kenaikan biaya produksi karena pergerakan kurs ini, pada akhirnya akan dibebankan pada harga barang yang diproduksinya. Dalam situasi perekonomian dalam negeri yang mengalami krisis, daya beli masyarakat tentunya mengalami penurunan. Hal ini berarti output yang dihasilkan produsen tersebut juga akan mengalami kesulitas dalam memasarkan produksinya di pasar.

Periode setelah krisis ekonomi, menunjukkan bahwa pergerakan nilai tukar mata uang Rp/ US\$ menunjukkan volatilitas yang semakin sering terjadi. Hal ini menandakan bahwa perekonomian nasional memiliki tingkat keterbukaan yang semakin besar seiring dengan penggunaan mata uang asing dalam transaksi ekonomi yang dilakukan oleh pelaku ekonomi nasional dan internasional. Pembentukan kawasan/blok perdagangan antar negara semakin mengintensifkan arus kegiatan ekonomi lintas negara. Dalam hal ini implementasi dari AFTA, CAFTA atau dalam skala yang lebih luas APEC dan WTO memberikan ruang perdagangan internasional yang lebih luas bagi semua negara. Dalam kondisi ini nilai tular mata uang Rp/US\$ akan terus mengalami volatilitasnya sesuai dengan kondisi permintaan dan penawaran mata uang $\mathrm{Rp} / \mathrm{US} \$$ di pasar uang.

Walaupun otoritas moneter telah melakukan intervensi di pasar uang dalam rangka menjaga stabilitas kurs pada level wajar, namun hal tersebut tidak menyurutkan pergerakan kurs yang segera mencapai stabilitasnya. Dalam hal ini pergerakan yang wajar pada tingkat basis poin yang kecil, pergerakan kurs masih bias ditolerir sebagai representasi dari dinamika yang terjadi di pasar uang. Namun manakala pergerakan nilai tukar mata uang (kurs) yang sudah overvalued/undervalued dan ekspektasi masyarakat sudah tidak rasional, maka intervensi dalam bentuk pembelian mata uang asing (US\$) atau penjualan mata uang asing (US\$) menjadi sebuah instrumen 
moneter yang sangat rasional. Meredam gejolak pergerakan nilai tukar mata uang agar tidak terlalu volatil menjadi sangat strategis manakala kegiatan ekspor dan impor dalam negeri menjadi primadona dalam mendorong pertumbuhan ekonomi nasional. Kegagalan dalam meredam gejolak nilai tukar mata uang Rp/US\$ akan membawa perekonomian pada kembali kondisi krisis ekonomi yang pernah terjadi pada tahun 1997/1998 di Indonesia.

\section{E. KESIMPULAN}

Volatilitas nilai tukar mata uang Rp/US\$ sebelum krisis ekonomi pada tahun 1997/1998 menunjukkan pergerakan yang relatif rendah dan stabil. Hal ini sebagai akibat dari sistem nilai tukar yang dianut yang menerapkan sistem nilai tukar mengambang terkendali. Dalam konteks ini intervensi dari otoritas moneter sangat dominan dalam menjaga pergerakan nilai tukar mata uang Rp/US\$ agar tidak terlalu volatil. Namun demikian periode setelah krisis ekonomi menunjukkan adanya pergerakan nilai tukar mata uang Rp/US\$ yang semakin volatil. Kondisi nilai tukar mata uang setelah krisis ekonomi tahun 1997/1998 menunjukkan nilai tukar mata uang Rp yang mengalami depresiasi terhadap mata uang US\$ dibandingkan dengan periode sebelum krisis ekonomi. Selain itu pula pada periode setelah krisis ekonomi, volatilitas nilai tukar mata uang Rp/US \$ mengalami kenaikan dibandingkan dengan periode waktu sebelum krisis ekonomi terjadi. Puncak dari volatilitas nilai tukar mata uang Rp/US\$ terjadi pada periode 1997/1998 yang menandakan adanya kesenjangan antara penawaran dan permintaan terhadap mata uang asing (US\$) dibandingkan dengan mata uang lokal (Rp). Hal ini terjadi karena ekspektasi masyarakat yang tidak rasional dalam mensikapi krisis ekonomi yang terjadi. Sehingga perilaku ekonominya menjadi liar dan mencerminkan moral hazard yang tinggi.

Berkenaan dengan dinamika yang terjadi pada perkembangan nilai tukar mata uang $\mathrm{Rp} /$ US\$ tersebut, maka dibutuhkan beberapa kebijakan, diantaranya adalah:

a. Fokus kebijakan pada stabilitas nilai tukar mata uang Rp/US\$ dengan memperhatkan faktor ekspektasi masyarakat terhadap kondisi perekonomian. Hal ini dapat dilakukan dengan mencermati pola kegiatan ekonomi masyarakat yang terjadi, sehingga dapat lebih terkendali transaksi ekonominya.

b. Diperlukan instrumen keuangan lain dalam rangka untuk memperbanyak pilihan masyarakat dalam mengalokasikan dana yang dimilikinya. Hal ini tentunya juga dibarengi dengan memberikan insentif yang ada yang lebih menarik, sehingga dapat mengurangi konsentrasi terhadap salah satu instrument keuangan yang ada.

\section{DAFTAR PUSTAKA}

Abel, Andrew B and Ben S.Bernanke, 2004.Macroeconomic, Fifth Edition, Pearson Addison Wesley, New York

Adam, Cristopher M, 1991. Exchange Rate Volatility, Monetary Policy Adjustment and Price Hysteresis, School of Business Discussion Papers, Bond University, September 
Arize, Augustine.1995. The Effects of Exchange Rate Volatility on US Exports: An Empirical Investigation, Southern Economic Journal, No. 62: 34-43

Assery, A and Peel, D.A, 1991.'The Effects of Exchage Rate Volatility of Exports", Economic Letters: 173-177

Bailey, M.J.,Tavlas, G.S and Ulan M, 1986. "Exchange Rate Variability and Trade Performance: Evidence for the Big Seven Industrial Countries", Weltwirtscaftliches Archiv, 122:466-477

Baldwin, Richard, 1988.Sunk Cost Hysteresis, National Bureau of Economic Research Working Paper, No. 2911, Maret

Baldwin, R.E. dan P. Krugman, 1989. Persistent Trade Effects of Large Exchange Rate Shocks, Quarterly Journal of Economics, 104:635-655

Chou,W.L, 2000.'Exchange Rate Variability and China's Exports", Journal of Comparative Economics, 28:61-79

Dornbusch, Rudiger, 1976,"Expectations and Exchange Rate Dynamics", Journal of Political Economy, 84, 1976, 1161-1176

93-106

Foot, K.A dan P.D Kemplerer, 1989. Exchange Rate Pass-Through When Market Share Matters, The American Economic Review, 79: 637-654

Larson, Donald W.,Mauricio V.L.Bittencourt, Stanley R.Thompson, 2005.”An Examination of the Impacts of Exchange Rate Volatility on Sectoral Trade in the Mercosur", Paper, Prepared for Presentation ath the American Agricultural Economics Association Annual Meeting,Providence, Rhode Island, July 24-27:1-31

Pozo, Susan.1992.Conditional Exchange Rate Volatility and the Volume of International Trade; Evidence from the Early 1900s, The Review of Economics and Statistics, Vol.74,Issues 2,May:325329

Sarwono, H.A dan Peri Warjiyo. 1998.Mencari Paradigma Baru Manajemen Moneter dalam Sistem Nilai Tukar Fleksibel:Suatu Pemikiran untuk Penerapannya di Indonesia, Bulletin Ekonomi dan Moneter Perbankan, Juli:1-23

Schabl, Gunter.2007.Exchange Rate Volatility and Growth in Small Open Economies at The EMU Periphery, Working Paper Series, No.773, European Central Bank, July:1-47

Vergil, Hasan. 2002. Exchange Rate Volatility in Turkey and its Effect on Trade Flow, Journal of Economics and Social Research,Vol. 4(1):83-99

Zainal, Arindra Artasya. 2004. Exchange Rate Pass-Through, Exchange Rate Volatility, and Their Impact on Export: Evidence from Indonesian Data, Disertasi, Kansas University , 2010, Statistical Data, IMF Publications, Website http:/www.imf.org,diakses pada tanggal 20 September 